Jurnal Teknologi Informasi dan Ilmu Komputer (JTIIK)

Vol. 3, No. 3, September 2016, hlm. 180-187

\title{
EDMODO UNTUK MENINGKATKAN KUALITAS PERENCANAAN PROYEK DAN EFEKTIVITAS PEMBELAJARAN DI LINGKUNGAN PEMBELAJARAN YANG BERSIFAT ASINKRON
}

\author{
Admaja Dwi Herlambang ${ }^{1}$, Wahyu Nur Hidayat ${ }^{2}$ \\ ${ }^{1}$ Pendidikan Teknologi Informasi, Fakultas Ilmu Komputer, Universitas Brawijaya \\ ${ }^{2}$ Politeknik Negeri Malang \\ Email: ${ }^{1}$ herlambang@ub.ac.id,
}

(Naskah masuk: 8 Agustus 2016, diterima untuk diterbitkan:8 September 2016)

\begin{abstract}
Abstrak
Pengintegrasian produk Teknologi Informasi dan Komunikasi (TIK) di dalam pembelajaran asinkron merupakan langkah yang tepat untuk meningkatkan keahlian komunikasi yang efektif, memecahkan masalah, dan berpikir kritis, kreatif, adaptif, dan reflektif. E-learning adalah sebuah bentuk pembelajaran yang mengintegrasikan produk TIK. E-learning dilengkapi dengan fitur tata kelola seperti fasilitas komunikasi, pemantauan, dan evaluasi. Edmodo adalah alternatif media pembelajaran di lingkungan e-learning yang maтри memberikan tata kelola pembelajaran yang baik, mudah dioperasikan, dan memfasilitasi kelas digital yang besar. Sebuah eksperimen telah dilakukan untuk menguji Edmodo sebagai media pembelajaran yang bersifat asinkron dengan menggunakan metode penelitian pre-experimental design tipe one-group pretestposttest. Eksperimen dilakukan pada perkuliahan matakuliah Manajemen Proyek Sistem Informasi (MPSI), Fakultas Ilmu Komputer, Universitas Brawijaya. MPSI adalah matakuliah yang membekali mahasiswa dengan kompetensi komunikasi yang efektif, memecahkan masalah, berpikir kritis, dan kreatif dalam merencanakan sebuah proyek. Tujuan dari eksperimen yang dilakukan adalah apakah pemanfaatan Edmodo mampu meningkatkan kualitas perencanaan proyek dan apakah Edmodo merupakan media pembelajaran yang efektif untuk proses pembelajaran yang bersifat asinkron. Hasil eksperimen menunjukkan bahwa pemanfaatan Edmodo sebagai media e-learning yang bersifat asinkron untuk meningkatkan kualitas proyek pada matakuliah MPSI adalah sangat baik. Hal ini terbukti dengan kualitas perencanaan proyek yang meningkat dan nilai efektivitas yang sangat tinggi.
\end{abstract}

Kata Kunci: E-learning, Edmodo, asinkron, proyek

\begin{abstract}
Integrating Information and Communication Technology (ICT) product in asychronous learning was the right step to improve the skills of effective communication, problem solving, thinking critically, creatively, and reflectively. E-learning was a form of media learning that integrates ICT products. E-learning was equipped with learning management features such as communication facilities, monitoring, and evaluation. Edmodo was an alternative medium of e-learning that provide good learning management, easy to operate, and facilitate large digital classroom. An experiment was conducted to test Edmodo as an asynchronous learning medium. The experiment used pre-experimental research design, one-group pretest-posttest type. Experiment was conducted in Project Management of Information System (PMIS) lecture, Faculty of Computer Science, Brawijaya University. PMIS was subjects that equip students with the competencies of effective communication, problem solving, critical thinking, and creativity in planning a project. The purpose of the experiment was whether the use of Edmodo could improve the quality of project planning and whether Edmodo was an effective learning media for asynchronous learning process. The experiment results showed that the use of Edmodo as an asychronous e-learning media to improve the quality of the project in PMIS course was very good. It is proven that increased quality of project planning and the value of effectiveness was very high.
\end{abstract}

Keywords: E-learning, Edmodo, asynchronous, project

\section{PENDAHULUAN}

Perkembangan Teknologi Informasi dan Komunikasi (TIK) yang begitu pesat sangat berpengaruh dalam berbagai bidang kehidupan. Perkembangan tersebut secara langsung memberikan dampak yang positif terhadap kemajuan pendidikan. Penerapan TIK dalam bidang pendidikan dapat dimanfaatkan sebagai sarana komunikasi yang tidak terbatas ruang dan waktu untuk menggali ilmu pengetahuan secara global (Dryden \& Voss, 1999). Perkembangan TIK (e-learning, digital library, e-mail) tidak hanya dimanfaatkan oleh masyarakat pendidikan untuk pembelajaran saat ini, tetapi juga untuk 
mengatisipasi perubahan model pembelajaran di masa akan datang.

Kegiatan pembelajaran merupakan suatu proses komunikasi dan informasi dari pendidik ke peserta didik yang berisi informasi-informasi pengetahuan. Pendidik sebagai sumber informasi; media sebagai sarana penyajian ide, gagasan, dan materi pendidikan; serta peserta didik sebagai penerima informasi. Salah satu produk TIK yang dapat dimanfaatkan untuk menunjang pembelajaran adalah internet. Pemanfaatan media internet telah melahirkan konsep pembelajaran jarak jauh berbasis elektronik yang disebut dengan e-learning. Elearning merupakan proses pembelajaran yang memanfaatkan fasilitas internet sebagai salah satu sarana dan media dalam pembelajaran.

Data statistik yang dihimpun oleh Word Bank pada tahun 2014 menunjukkan bahwa pengguna aktif teknologi internet di Indonesia meningkat secara drastis sejak tahun 2004 (Word Bank, 2016). Artinya, dalam kurun waktu 10 tahun jumlah pengguna teknologi internet aktif di Indonesia meningkat dari 2600 orang menjadi 17000 orang. Data tersebut membuktikan bahwa ada potensi yang tinggi untuk memanfaatkan teknologi internet dalam memajukan pendidikan. Temuan dari riset oleh Educase pada tahun 2015 menunjukkan bahwa produk-produk TIK telah menyatu dengan kehidupan mahasiswa perguruan tinggi (Arroway, Yanosky, Brooks, Thayer, \& Morgan, 2015). Produk TI yang digunakan mahasiswa didominsasi oleh produk berjenis internet capable device, yaitu produk yang terkoneksi dengan teknologi internet. Kondisi mahasiswa di tahun 2015 disebut sebagai more well prepared condition dalam penggunaan TIK untuk semua aktifitas di perguruan tinggi apabila dibandingkan dengan keadaan pada tahun 2012. Irisan temuan dari Word Bank dan Educase membuktikan bahwa ada peluang yang bagus untuk memanfaatkan teknologi internet di dalam proses pembelajaran perguruan tinggi. Tidak perlu ada alasan lagi bahwa sulit untuk mengintegrasikan produk TIK di dalam proses pembelajaran di perguruan tinggi karena keterbatasan akses mahasiswa terhadap teknologi pendukungnya.

Peraturan Menteri Pendidikan dan Kebudayaan Republik Indonesia Nomor 49 Tahun 2014 tentang Standar Nasional Pendidikan Tinggi pasal 14 menyebutkan bahwa proses pembelajaran melalui kegiatan kurikuler wajib menggunakan metode pembelajaran yang efektif. Efektif pada peraturan tersebut mempunyai arti bahwa proses pembelajaran harus menggunakan waktu secara optimum dan bersifat kolaboratif. Artinya, interaksi antara dosen dan mahasiswa harus tetap terjaga dan semua materi terinternalisasi dengan baik sesuai dengan waktu yang telah direncanakan. Kriteria yang disampaikan pada peraturan tersebut sebenarnya bisa dicapai dengan memanfaatkan produk TIK atau peran teknologi untuk mendukung proses pembelajaran di dalam kelas.

Fakta di lapangan menunjukkan bahwa proses pembelajaran masih didominasi dengan cara bertatap muka secara langsung (face-to-face), seperti halnya kegiatan perkuliahan yang dilakukan di Jurusan Sistem Informasi, Fakultas Ilmu Komputer, Universitas Brawijaya. Hasil observasi yang dilakukan oleh peneliti menunjukkan bahwa model pembelajaran yang dilakukan masih didominasi dengan aktivitas bertatap muka secara langsung. Teknologi sudah berperan di dalam proses pembelajarannya, namun masih belum dominan. Pembelajaran ini yang masih cenderung disebut dengan model pembelajaran konvensional karena peran teknologi masih sangat kecil. Teknologi hanya digunakan untuk mendistribusikan informasi atau sumber belajar saja, seperti group messenger, $e$ book, atau job sheet. Survey di lapangan menujukkan bahwa pembelajaran secara konvensional memiliki kelebihan dan kekurangan. Data didapatkan dengan alat ukur angket dan disebar kepada 100 mahasiswa Sistem Informasi, Fakultas Ilmu Komputer, Universitas Brawijaya secara acak. Hasil survey menunjukkan bahwa kelebihan pembelajaran konvensional, yaitu: (1) dosen secara langsung dapat memantau perkembangan mahasiswa dari awal hingga akhir proses pembelajaran $(80,25 \%)$; dosen dapat berkomunikasi secara langsung dengan mahasiswa (90,76\%); dan (3) dosen dapat menilai secara langsung kemampuan setiap mahasiswa $(89,81 \%)$.

Di samping memiliki kelebihan, terdapat pula kekurangan dari pembelajaran konvensional, yaitu: (1) terkait sumber belajar yang digunakan terbatas sehingga pengetahuan mahasiswa hanya terpaku pada sumber belajar yang ditetapkan oleh dosen yang mengakibatkan pengetahuan atau wawasan mahasiswa terbatas $(80,56 \%)$; (2) proses pembelajaran berlangsung secara monoton dan kurang menyenangkan $(93,74 \%)$; dan (3) perihal pengumpulan dan pengerjaan tugas yang diberikan oleh dosen, mahasiswa sering kali kurang disiplin dan tidak tepat waktu $(79,80 \%)$. Berdasarkan dari temuan tersebut, maka perlu dikembangkan proses pembelajaran yang dapat melibatkan peran perkembangan teknologi didalamnya secara maksimal. Peran teknologi di dalam proses pembelajaran diasumsikan dapat mengecilkan munculnya kekurangan pada pembelajaran konvensional sehingga bisa mencapai karakter pembelajaran yang efektif dan kolaboratif.

Perkembangan teknologi yang ada juga mempengaruhi sistem tata kelola maupun pelaksanaan kegiatan perkuliahan. Pemanfaatan TIK dalam sistem pembelajaran telah mengubah sistem pembelajaran pola konvensional atau pola tradisional menjadi pola modern yang bermedia (Paryono dan Quito, 2010; Aunurrahman, 2012; Dharma dkk, 2013 dan Husamah, 2014). 
Pengintegrasian TIK dalam pembelajaran merupakan langkah yang tepat untuk pembelajaran yang berpusat pada peserta didik (students centered), meningkatkan keahlian komunikasi yang efektif, kemampuan memecahkan masalah, dan keahlian berpikir kritis, kreatif, adaptif, dan reflektif (Gray, 2012). Sayangnya, perkembangan TIK yang begitu pesat belum dimanfaatkan secara optimal dalam proses pembelajaran (Tamba, 2011; dan Samuel \& Zaitun, 2007)

Menurut Patmanthara (2014), e-learning adalah pembelajaran berbantuan TIK dengan menggunakan piranti elektronik, jaringan, dan perangkat lunak pengajaran yang dilengkapi dengan fasilitas komunikasi, pemantauan, dan evaluasi. E-learning dapat didefinisikan sebagai sebuah bentuk dunia maya untuk membuat sebuah transformasi proses pembelajaran di sekolah atau perguruan tinggi ke dalam bentuk digital yang dijembatani teknologi internet (Clark \& Mayer, 2008; Munir, 2009; dan Rusman, dkk, 2011). Hasil riset Said, Kirgis, Verkamp, \& Johnson (2015) membuktikan bahwa $e$ learning mampu memberikan hasil yang lebih baik dari sisi hasil pembelajaran mahasiswa di perguruan tinggi daripada model pembelajaran face-to-face.

Syarat untuk membangun e-learning yang efektif untuk perguruan tinggi, yaitu: (1) desain konten kuliah yang baik; (2) dosen memfasilitasi diskusi; (3) dosen aktif merespon pertanyaan dari mahasiswa; (4) dosen mendesain tugas dengan tepat; dan (5) dosen mengevaluasi hasil pembelajaran mahasiswa (Sun \& Chen, 2016). Eksperimen yang dilakukan oleh Hanum (2013) menunjukkan bahwa e-learning dapat memfasilitasi interaksi kelas sebesar 66,10\%. Artinya, interkasi dosen dan mahasiswa di dalam e-learning sudah cukup efektif. Teknologi memang tidak bisa menggantikan peran dosen secara penuh di dalam pembelajaran. Salah satunya adalah peran dosen sebagai motivator di dalam pembelajaran. Peran dosen sebagai motivator adalah alasan mengapa interaksi antara dosen dan mahasiswa harus tetap terjaga walaupun dijembatani oleh teknologi informasi. Bahkan kualitas interaksi harus lebih tinggi karena teknologi e-learning memungkinkan komunikasi yang tidak terbatas oleh ruang dan waktu. Hasil riset Saade \& Sharhan (2015) menunjukkan bahwa kuatnya minat mahasiswa untuk tetap menggunakan e-learning adalah interaksi berupa motivasi yang timbul dari sumber luar. Dosen adalah salah satu sumber luar untuk memberikan motivasi kepada mahasiswa melalui interaksi yang terjadi melalui perangkat teknologi. Selain itu, riset Kosasi (2015) menunjukkan bahwa e-learning sendiri juga mampu mampu meningkatkan motivasi karena keinteraktifannya. Artinya, e-learning mampu menambah kualitas interaksi dosen dan mahasiswa apabila memanfaatkan fitur komunikasi yang ada di dalamnya, seperti group chat, comment, quiz, dan lain sebagainya.
Hasil survey di lapangan menunjukkan bahwa e-learning sudah dimanfaatkan untuk mendukung proses pembelejaran di dalam perkuliahan di Jurusan Sistem Informasi, Fakultas Ilmu Komputer, Universitas Brawijaya. Salah satu bentuk e-learning yang dimanfaatkan dapat diakses di vlm.ub.ac.id. Hasil survey kepada 100 mahasiswa secara acak menunjukkan bahwa keefektifan e-learning hanya mendapatkan skor sebesar $40,35 \%$ yang artinya pemanfaatan $e$ learning masih sangat kecil dan masih cenderung menggunakan model pembelajaran konvensional. Pemanfaatan e-learning tersebut hanya didominasi aktifitas untuk mendistribusikan bahan perkuliahan dan ujian dengan butir soal berbentuk pilihan ganda saja. Peneliti kemudian mencoba alternatif lain untuk meningkatkan pemanfaatan e-learning dengan menggunakan media lain, yaitu Edmodo. Keputusan untuk memilih Edmodo sebagai alternatif media pembelajaran di lingkungan $e$ learning adalah karena Edmodo mampu memberikan tata kelola pembelajaran yang lebih baik dan mudah. Edmodo mempunyai kemampuan untuk memfasilitasi kelas digital dan komunitas pembelajaran yang besar dan efektif (Cherner, Lee, Fegely, \& Santaniello, 2016).

Peneliti melakukan eksperimen pada perkuliahan Manajemen Proyek Sistem Informasi (MPSI). Berdasarkan temuan di lapangan, matakuliah MPSI adalah matakuliah yang berkriteria proyek, dimana mahasiswa dituntut untuk merencakan dan mengeksekusi proyek di lapangan. Pengelolaan kelas cenderung didesain agar mahsiswa lebih banyak beraktifitas di luar kelas untuk merancang proyek. Hasil observasi pada matakuliah MPSI menunjukkan bahwa model pembelajaran yang digunakan masih cenderung konvensional sehingga jam efektif perkuliahan banyak dihabiskan di dalam kelas. Artinya, perlu digunakan model lain untuk memfasilitasi matakuliah berkriteria seperti MPSI. Hasil evaluasi tengah semester juga menunjukkan bahwa rerata nilai perencanaan proyek mahasiswa adalah 58,75 yang artinya masih di bawah kategori tinggi. Kualitas perencanaan proyek dapat dinilai dari beberapa indikator, yaitu: (1) kualitas company profile; (2) kualitas project charter; (3) kualitas team contract; (4) kualitas software requirement specification; (5) kualitas financial analysis; (6) kualitas project schedule; dan (7) kelengkapan dokumen pendukung.

\section{METODE}

Penelitian ini menggunakan metode penelitian pre-experimental design dengan model one-group pretest-posttest design yaitu desain eksperimen dengan cara membandingkan keadaan sebelum dan sesudah perlakuan pada satu kelas eksperimen (Creswell 2009:158-159; Fraenkel dan Wallen, 2009:265; Sugiyono, 2009:110; dan Emzir, 
2010:96). Keefektifan sistem manajemen pembelajaran diukur dengan cara membandingkan kompetensi peserta sesudah perlakukan $\left(\mathrm{O}_{2}\right)$ dengan kemampuan peserta sebelum perlakuan $\left(\mathrm{O}_{1}\right)$. Perbedaan skor $\mathrm{O}_{1}$ dengan $\mathrm{O}_{2}$ dianalisis menggunakan uji-t.

Penelitian pre-eksperimen ini dilakukan di Program Studi Sistem Informasi, Univeristas Brawijaya pada semester genap tahun ajaran 2015/2016. Subjek penelitian adalah satu kelas pada matakuliah MPSI berjumlah 45 mahasiswa dan pemberi perlakuan (instruktur) adalah dosen.

Instrumen penelitian dibagi menjadi dua yaitu instrumen perlakuan dan instrumen pengukuran. Instrumen perlakuan ini berupa instrumen perangkat pembelajaran yang terintegrasi dengan sistem elearing pada matakuliah MPSI Instrumen pengukuran digunakan untuk mengukur hasil belajar mahasiswa setelah melakukan pembelajaran menggunakan media e-learning dan untuk mengetahui efektivitas perkuliahan menggunakan $e$ learning. Sistem e-learning menggunakan edmodo sebagai Learning Management System (LMS). Instrumen pengukuran dalam penelitian ini terdiri dari dua macam, yaitu: tes objektif dan angket respon mahasiswa untuk mengetahui efektvitas sistem.

Sesuai dengan teknik pengumpulan data, instrumen yang digunakan dalam penelitian ini adalah tes objektif dan angket. Instrumen dikembangkan berdasarkan variabel penelitian dengan prinsip garpu tala dengan cara menelaah konstruk variabel penelitian, menerjemahkan dalam bentuk kisi-kisi, dan menelaah kondisi di lapangan. Sebelum digunakan untuk mengambil data, instrumen terlebih dahulu divalidasi isi oleh ahli (expert judgement) dan dilakukan validasi konstruk secara empirik di lapangan. Hasil validasi ahli masuk dalam kriteria sangat tinggi, sedangkan hasil uji validasi konstruk (validasi butir) menunjukkan bahwa keseluruhan butir masuk dalam kriteria valid. Analisis selanjutnya adalah uji reliabilitas instrumen, dengan hasil realibilitas masuk dalam kategori sangat reliabel. Tes objektif berupa tugas proyek dan angket respon mahasiswa menggunakan skala likert dengan empat alternatif jawaban, yaitu tidak baik (1), kurang baik (2), baik (3), dan sangat baik (4).

Sesuai dengan tujuan penelitian dan jenis data yang ada, teknik analisis data yang digunakan adalah teknik analisis uji beda (uji-t) dan analisis deskriptif kuantitatif. Analisis uji-t digunakan untuk memperoleh informasi peningkatan hasil belajar mahasiswa melalui uji perbedaan nilai pretest dan postest. Analisis deskriptif memberikan gambaran secara sistematis data yang faktual dan akurat mengenai fakta-fakta tentang efektivitas penggunaan e-learning pada mata kuliah pembelajaran berbantuan komputer yang disajikan dalam bentuk tabel, grafik, atau diagram. Langkah-langkah untuk menganalisis data kuantitatif yaitu: memberikan skor pada setiap indikator; menentukan nilai rerata; menentukan nilai modus; dan menafsirkan makna. Berdasarkan data yang diperoleh dari kuesioner, analisis dan interpretasi dilakukan pada tiap indikator. Teknik analisis deskriptif yang digunakan adalah dengan pemakaian tabel frekuensi, persentase rerata masing-masing butir digunakan Persamaan (1). Pada Persamaan (1) P adalah persentase yangg dicari, $\mathrm{F}$ adalah skor tiap indikator, dan $\mathrm{N}$ adalah skor ideal (Sudjana, 2005).

$$
P=\frac{F}{N} \times 100 \%
$$

Hasil perhitungan persentase kemudian dikonsultasikan pada kategori penafsiran skor dalam analisis deskriptif data sebagaimana pada Tabel 1 . Tabel 1 dihasilkan berdasakan teori skor distribusi normal.

Tabel 1 Kategori Penafsiran Skor dalam Analisis Deskriptif

\begin{tabular}{|c|c|c|}
\hline No. & Persentase (\%) & Kategori \\
\hline 1 & $\begin{array}{l}83,34<\mathrm{P} \leq \\
100,00\end{array}$ & $\begin{array}{l}\text { Sangat baik/ Sangat } \\
\text { tinggi }\end{array}$ \\
\hline 2 & $79,17<\mathrm{P} \leq 83,34$ & Baik/ tinggi \\
\hline 3 & $50,00<\mathrm{P} \leq 79,17$ & Kurang Baik/ rendah \\
\hline 4 & $0,00<\mathrm{P} \leq 50,00$ & $\begin{array}{l}\text { Tidak Baik/ sangat } \\
\text { rendah }\end{array}$ \\
\hline
\end{tabular}

\section{HASIL DAN PEMBAHASAN}

Data ini merupakan kemampuan awal peserta sebelum mengikuti kegiatan pembelajaran matakuliah MPSI yang diperoleh dari nilai pretest dan data hasil belajar yang didapat dari nilai posttest setelah mengikuti kegiatan pembelajaran menggunakan e-learning. Data pretest dan postest mahasiswa selengkapnya dapat dilihat pada Tabel 2.

\begin{tabular}{ccccc} 
Tabel 2 & Deskripsi Data Prestest dan Postest \\
\hline MPSI & $\begin{array}{c}\text { Nilai } \\
\text { Tertinggi }\end{array}$ & $\begin{array}{c}\text { Nilai } \\
\text { Terendah }\end{array}$ & $\begin{array}{c}\text { Skor } \\
\text { rerat } \\
\text { a }\end{array}$ & $\begin{array}{c}\text { Std } \\
\text { deviasi }\end{array}$ \\
\hline Prestest & 75,00 & 45,00 & 61,00 & 17,79 \\
Postest & 100,00 & 70,00 & 82,00 & 12,65 \\
\hline
\end{tabular}

Pada Tabel 2 dapat diketahui bahwa pada matakuliah MPSI skor rerata prestest sebesar 61,00 dan posttest sebesar 82,00 . Sedangkan untuk standar deviasi untuk nilai pretest sebesar 17,79 dan nilai posttest sebesar 12,65. Berdasarkan data tersebut 
dapat diketahui bahwa nilai posttest lebih besar daripada nilai pretest.

Hasil pengujian hipotesis yang dipaparkan dalam penelitian ini adalah hasil uji beda hasil belajar mahasiswa pada matakuliah MPSI sebelum dan sesudah mengikuti pembelajaran berbasis e-learning menggunakan Edmodo sebagai media pembelajaran yang bersifat asinkron. Hasil uji beda nilai pretest dan posttest dapat dilihat pada Tabel 3. Penerimaan atau penolakan terhadap hipotesis didasarkan pada besarnya nilai $t_{\text {hitung }}$ dibandingkan $t_{\text {tabel }}$ atau angka signifikansi (Sig.).

Pada Tabel 3 dapat diketahui bahwa nilai $t_{\text {hitung }}$ dari data mahasiswa Program Studi Sistem Informasi lebih besar daripada $\mathrm{t}_{\text {tabel }}(-10,396>$ 2,014), sehingga dapat dikatakan bahwa terdapat perbedaan yang signifikan antara data pretest dan posttest. Sedangkan jika dilihat dari nilai Sig. (Sig. = 0,000 ) yang kurang dari 0,05 , mempunyai arti bahwa pembelajaran dengan menggunakan media $e$ learning lebih dapat meningkatkan kualitas perencanaan proyek daripada model pembelajaran yang selama ini berlangsung pada matakuliah MPSI. Dengan kata lain, pemanfaatan Edmodo sebagai media pembelajaran e-learning memberikan dampak yang positif terhadap kualitas perencanaan proyek matakuliah MPSI. Temuan ini sejalan dengan teori yang dikemukakan oleh Fry, Steve, \& Marshall (2009). Fry, Steve, \& Marshall (2009) menyatakan bahwa pembelajaran berbasis $e$-learning yang efektif dapat memberikan tuntunan sukses untuk peserta didik, baik melalui pembelajaran reguler maupun pembelajaran mandiri.

\section{Tabel 3 Hasil Uji Beda Data Pretest dan Posttest pada Uji Coba Lapangan}

\begin{tabular}{lccccc}
\hline MPSI & $\mathbf{N}$ & $\bar{x}$ & Sig. & $\mathbf{t}_{\text {hitung }}$ & $\mathbf{t}_{\text {tabel }}$ \\
\hline Prestest & 45 & 61,00 & 0,000 & $-10,396$ & 2,014 \\
Postest & 45 & 82,00 & & & \\
\hline
\end{tabular}

Setelah diketahui bahwa pemanfaatan Edmodo sebagai media e-learning mampu meningkatkan kualitas perencanaan proyek matakuliah MPSI, maka analisis dilanjutkan dengan penilaian mahasiswa terhadap efektivitas media e-learning yang digunakan dalam pembelajaran. Penilaian terhadap efektivitas media e-learning didasarkan kepada delapan aspek seperti yang tertuang pada Tabel 4.

Pada Tabel 4 diketahui bahwa rata-rata efektivitas media e-learning adalah 83,61 dengan kategori sangat baik. Pembelajaran menggunakan media e-learning ini memungkinkan keleluasaan individu yang berbeda. Mahasiswa melakukan aktivitas belajar dengan gaya dan cara yang berbeda (individual differences). Keadaan ini dapat dijelaskan dari berbagai alternatif yang harus ditempuh oleh mahasiswa selama mengikuti matakuliah MPSI, misalnya dalam melakukan interaksi antar-mahasiswa, mahasiswa dengan dosen, maupun forum satu kelas. Pembelajaran ini juga mensinergikan antara modus dan cara belajar yang mampu menumbuhkan kreativitas dan kemandirian belajar.

Tabel 4 Data Hasil Uji Efektivitas Media $E$ -

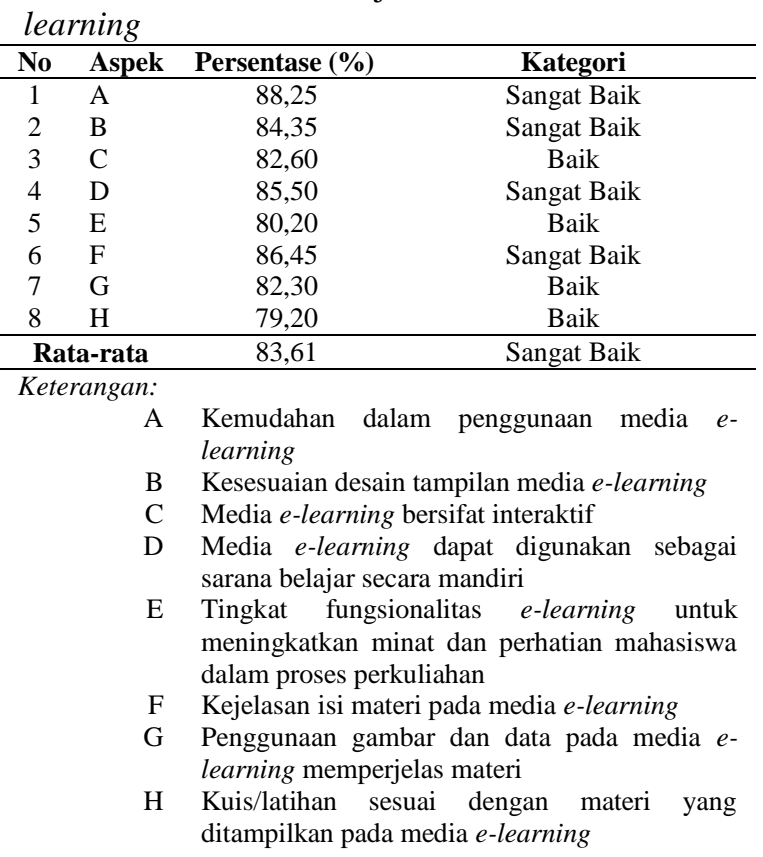

Temuan penelitian menunjukkan bahwa kemudahan dalam penggunaan Edmodo sebagai media e-learning masuk dalam kategori sangat baik (mean=88,25). Hal ini berarti bahwa media tersebut sangat user friendly dengan kelengkapan fitur yang sesuai dengan kebutuhan pembelajaran. Mahasiswa juga memberikan respon yang sangat baik (mean=84,35) terhadap kesesuaian desain dan tampilan media e-learning. Selain sesuai dengan jenis mata kuliah, juga sesuai dengan perkembangan psikologis mahasiswa.

Mahasiswa memberikan respon baik (mean=82,60) terhadap sifat media e-learning sebagai media interaktif. Hasil temuan tersebut selaras dengan pendapat Bates dan Wulf (dalam Siahaan, 2002) yang menjelaskan manfaat dari pembelajaran online adalah dapat meningkatkan kadar interaksi pembelajaran antara dosen dan mahasiswa, dan memungkinkan terjadinya interaksi pembelajaran dimanapun dan kapanpun. Dosen berperan sebagai pengelola yang "mengorkestrakan" aktivitas belajar melalui media e-learning. Hal ini terefleksikan pada skenario pembelajaran yang menempatkan peran dosen sebagai fasilitator dalam aktivitas pembelajaran. Representasi peran fasilitator dalam hal ini ditunjukkan dengan adanya komitmen yang selalu siap untuk memfasilitasi interaksi mahasiswa melalui fitur-fitur yang tersedia pada media e-learning.

Hasil empirik penelitian ini menunjukkan bahwa Edmodo sebagai media e-learning sangat baik 
digunakan sebagai sarana belajar mandiri (mean=85,50) dan baik untuk meningkatkan minat dan perhatian mahasiswa dalam proses perkuliahan (mean=80,20). Hasil tersebut sesuai dengan pendapat Hiemstra (2006) yang menyatakan bahwa web mendukung kemandirian belajar dan diperkuat dengan hasil penelitian Sakdiah, dkk (2015) yang menyatakan bahwa pembelajaran inkuiri berbasis web dapat meningkatkan kemandirian belajar mahasiswa. Melalui media e-learning, mahasiswa dapat memperkaya pengetahuan dan menggali pengetahuan lebih dalam melalui materi yang telah disajikan dalam media. Selain itu, melalui e-learning mahasiswa juga dapat berinteraksi antar mahasiswa atau mahasiswa dengan dosen.

Penilaian mahasiswa pada aspek kejelasan materi yang diupload dosen pada media e-learning masuk dalam kategori sangat baik (mean=86,45). Hal ini mempunyai makna bahwa materi yang dipersiapkan kemudian disajikan dalam media telah disesuaikan dengan kebutuhan pembalajaran matakuliah MPSI. Selain itu, penggunaan gambar sebagai bahan ilustrasi dan penggunaan data sebagai penguat materi pembelajaran masuk dalam kategori baik (mean=82,30). Penggunaan gambar dan data sebagai penguat materi pembelajaran sangat dimungkinkan untuk ditampilkan pada media e-learning mengingat space media ini sangat besar. Bahkan melalui Edmodo, dosen dapat membuat perpustakaan pembalajaran sebagai tempat bahan refensi yang berhubungan dengan materi perkuliahan.

Respon mahasiswa terhadap fitur kuis/latihan yang terdapat pada Edmodo masuk dalam kategori baik (mean=79,20). Aktivitas belajar mahasiswa dalam memanfaatkan kuis online sangat bervariasi. Menurut Rouf (2011) aktivitas peserta didik dalam kuis online dapat menjadi alat ukur kemandirian belajar peserta didik. Fasilitas kuis online pada Edmodo masih memiliki kelemahan, sehingga respon dan aktivitas belajar mahasiswa menggunakan kuis online tergolong belum memuaskan. Salah satu hal yang menjadi kelemahan adalah tidak adanya fitur umpan balik (feedback). Penilaian dan catatan latihan dalam kuis online mempengaruhi ketertarikan mahasiswa dalam mengerjakan kuis.

Berdasarkan hasil penelitian tersebut dapat disimpulkan secara keseluruhan bahwa efektivitas pemanfaatan LMS pada perkuliahan pembelajaran berbantuan komputer ditinjau dari hasil belajar mahasiswa dan angket, masuk dalam kategori sangat baik. Dengan hasil tersebut maka dalam mata kuliah lainnya, konsep pemanfaatan LMS dalam perkuliahan dapat digunakan sebagai diversifikasi pembelajaran dengan model e-learning menggunakan edmodo. Pemanfaatan LMS dalam perkuliahan dilakukan untuk meningkatkan kualitas pembelajaran melalui metode pengajaran dari metode pasif menjadi metode partisipatif dengan bantuan teknologi.
Edmodo merupakan jejaring sosial untuk pembelajaran berbasis Learning Managent System (LMS). Edmodo memberi fasilitas bagi dosen dan mahasiswa, tempat yang aman untuk berkomunikasi, berkolaborasi, berbagi konten dan aplikasi pembelajaran, tugas bagi mahasiswa, diskusi dalam kelas virtual, ulangan secara online, nilai dan diskusi. Pada intinya edmodo menyediakan semua yang bisa dilakukan di kelas dalam kegiatan pembelajaran. Edmodo pada dasarnya merupakan sebuah situs yang diperuntukan bagi pendidik untuk membuat kelas virtual. Situs tersebut bersifat gratis dan gampang digunakannya selama dosen dan mahasiswa terhubung dengan internet. Proses pembelajaran menggunakan Edmodo ditunjukkan pada Gambar 1.

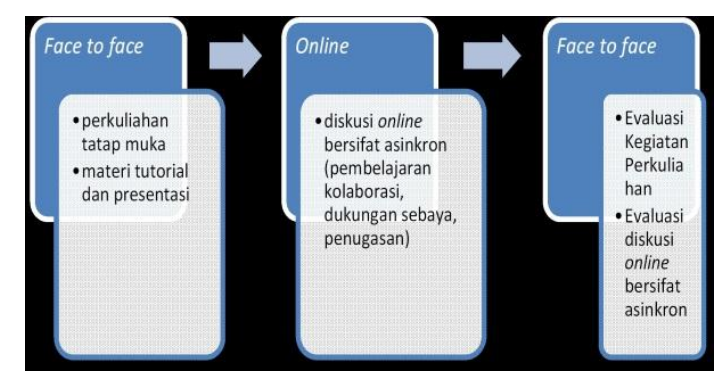

Gambar 1 Desain Proses Pembelajaran Menggunakan Edmodo sebagai LM

Seiring dengan skenario pembelajaran yang tercantum di atas, pembelajaran memanfaatkan situs jejaring sosial, seperti Edmodo, menawarkan kesempatan unik untuk menghubungkan dosen dengan mahasiswa dan membantu mahasiswa menciptakan norma-norma pembelajaran. Sintaks pembelajaran berbantuan edmodo sebagai LMS merupakan cerminan model pembelajaran blended learning. Model ini mensinergikan pembelajaran tatap muka (face to face) dengan pembelajaran (online) yang saling melengkapi. Pada gambar 1 ditunjukkan bahwa pembelajaran tatap muka dimulai dengan penjelasan materi oleh dosen sesuai dengan intruksional pembelajaran dengan metode presentasi. Selanjutnya dilanjutkan dengan pembelajaran online yang berisi kegiatan pembelajaran mandiri, diskusi, dan kolaborasi antara dosen dan mahasiswa melalui serangkaian kegiatan online, seperti sharing materi, diskusi terbatas, dan pengerjaan evaluasi. Sintaks terakhir dilengkapi dengan kegiatan tatap muka sebagai tahapan evaluasi terhadap pembelajaran yang telah dilaksanakan, baik evaluasi kegiatan perkualiahan dan pembelajaran online. Sintaks model pembelajaran menggunakan edmodo sebagai LMS ini digunakan untuk meningkatkan hasil belajar dan efektivitas pembelajaran yang dilihat dari kemudahan, kesesuaian, dan tingkat fungsionalitas LMS.

Faktor pendukung penerapan LMS dalam perkuliahan juga harus didukung oleh kompetensi TIK yang dimiliki oleh dosen. Investasi pengembangan diri dosen dalam pemanfaatan TIK 
dapat memberikan kontribusi positif, baik peserta didik maupun bagi dosen sendiri (Sujianto, Mukhadis, dan Isnandar, 2012; dan Munadi, 2009). Melalui pemanfaatan TIK dalam pembelajaran dosen dan mahasiswa dapat bekerjasama dalam belajar, diskusi, berbagi informasi, dan menemukan pengetahuan.

Sebagian besar dosen sebenarnya telah menggunakan TIK dalam perkuliahan yang digunakan untuk menyiapkan perkuliahan, melakukan presentasi, dan melaksanakan evaluasi mahasiswa (Singh \& Samili, 2014; dan Samuel \& Zaitun, 2007). Dosen sebenarnya sudah memanfaatkan TIK khususnya komputer pada tahap penyiapan, pelaksanaan, dan evaluasi secara sederhana, namun untuk pemanfaatan TIK secara lebih canggih dan spesifik belum diterapkan. Oleh karena itu keterampilan dosen dalam bidag TIK khususnya dalam pemanfaatan LMS perlu ditingkatkan (Keengwe \& Onchwari, 2011; dan Simonson, 2008).

\section{SIMPULAN}

Simpulan yang dapat dirumuskan dari eksperimen yang telah dilakukan adalah pemanfaatan Edmodo sebagai media e-learning yang bersifat asinkron untuk meningkatkan kualitas proyek pada matakuliah MPSI sangat baik. Hal ini terbukti dari peningkatkan kualitas proyek mahasiswa dan nilai efektivitas media e-learning yang sangat tinggi. Dari simpulan yang ada, dapat disarankan bagi dosen untuk meningkatkan kompetensi TIK yang mendukung konsep integrasi TIK dalam proses perkuliahan. Salah satu integrasi TIK dalam yang dapat diterapkan dalam perkuliahan adalah pemanfaatan media e-learning. Peningkatan kompetensi tersebut dapat dilakukan dengan cara belajar otodidak, mengikuti sistem magang pada rekan sesama dosen yang telah memanfaatkan media e-learning dalam perkuliahan, dan mengikuti pelatihan. Universitas dituntut untuk dapat memfasilitasi dosen dalam rangka peningkatan kompetensi TIK dengan cara menyelenggarakan kegiatan pelatihan TIK secara berkala. Dengan demikian, jika penyelenggaraan pelatihan TIK secara rutin dan berkelanjutan dilaksanakan di sekolah, tingkat integrasi TIK dalam pembelajaran dapat meningkat dan berpengaruh pada hasil belajar mahasiswa dan membentuk dosen yang profesional.

\section{DAFTAR PUSTAKA}

Arroway, P., Yanosky, R., Brooks, D.R., Thayer, T.L., \& Morgan, G. 2015. Analytics in Higher Education, laman web: https://library.educause.edu/resources/2015/ 5/analytics-in-higher-education-2015 [diakses 1 Agustus 2016].

Aunurrahman. 2012. Belajar dan Pembelajaran. Bandung: Alfabeta.
Cherner, T., Lee, C-Y., Fegely, A., \& Santaniello, L. 2016. "A Detailed Rubric for Assessing the Quality of Teacher Resource Apps". Journal of Information Technology Education: Innovations in Practice. Vol. 15, 2016, laman web: http://www.informingscience.org/Publicatio ns/3527 [diakses 1 Agustus 2016].

.Clark, R.C. \& Mayer, R.E. 2008. E-Learning and The Science of Instruction: Proven Guidelines for Consumers and Designers of Multimedia Learning, Second Edition. San Francisco: John Wiley \& Sons, Inc.

Creswell, J.W. 2009. Research Design: Qualitative, Quantitative, and Mixed Methods Approach. California: Sage Publications.

Dryden \& Voss. 1999. The Learning Revolution: To Change the Way the World Learn. The Learning Web, laman web: http://www.thelearningweb.net [diakses 1 Agustus 2016]

Emzir. 2010. Metodologi Penelitian Pendidikan: Kuantitatif \& Kualitatif. Jakarta: Rajawali Pers.

Fraenkel, J.R dan Wellen, N.E. 2009. How to Design and Evaluate Research in Education. New York: McGraw-Hill.

Fry, H, Steve, K, \& Marshall, S. 2009. A Handbook for Teaching and learning in Higher Education: Enhancing Academic Practice (Third Edition). New York: Routledge.

Gray, Tessa. 2012. Rich ICT Learning Experiences: What Do They Look Like?, laman web: http://elearning.tki.org.nz/ [diakses $16 \mathrm{Mei}$ 2016].

Hanum, N.S. 2013. "Keefektifan E-learning sebagai Media Pembelajaran". Jurnal Pendidikan Vokasi, Vol. 3, Nomor 1, Februari 2013.

Husamah. 2014. Pembelajaran Bauran (Blended Learning). Jakarta: Prestasi Pustaka.

Keengwe, J. \& Onchwari, G. 2011. Computer Technology Integration and Student Learning: Barriers and Promise. Journal of Science Education and Technology. 17: 560-570.

Kosasi, S. 2015. "Perancangan E-learning untuk Meningkatkan Motivasi Belajar Guru dan Siswa". Prosiding Seminar Nasional Pendidikan Teknik Informatika, Singaraja, Bali, 12 September 2015.

Marchewka, J.T. 2015. Information Technology Project Management: Providing Measurable Organizational Value. USA: John Wiley \& Sons, Inc.

Munadi, S. 2009. Implementasi Transformasi Teknologi dalam Meningkatkan Kualitas Pembelajaran Kejuruan Bidang Teknik, 
laman http://staff.uny.ac.id/, [diakses 1 Agustus 2016]..

Munir. 2009. Pembelajaran Jarak Jauh Berbasis Teknologi Informasi dan Komunikasi. Bandung: Alfabeta.

Paryono \& Quito, B. 2010. Meta-analysis of ICT Integration in Vocational and Technical Education in Southeast Asia, laman web: http://www.voctech.org.bn/] [diakses 1 Agustus 2016].

Patmanthara, Syaad. 2014. Pembelajaran Berbantuan Komputer. Jember: Cerdas Ulet Kreatif.

Peraturan Menteri Pendidikan dan Kebudayaan Republik Indonesia Nomor 49 tentang Standar Nasional Pendidikan Tinggi. Badan Standar Nasional Pendidikan, laman web: http://bsnp-indonesia.org/ [diakses 1 Agustus 2016].

Rouf, A. 2011. "Assesment of Self Directed Learning by Comprehensive Online Test". International Journal of Biology Education. Vol. 1, No. 1. 2011.

Rusman, dkk. 2011. Pembelajaran Berbasis Teknologi Informasi dan Komunikasi, Mengembangkan Profesionalitas Guru. Jakarta: PT. Raja Grafindo.

Saade, R.G., \& Sharhan, J.A. 2015. "Discovering the Motivations of Students when Using an Online Learning Tool". Journal of Information Technology Education: Reasearch. Vol. 14, 2015, laman web: http://www.informingscience.org/Publicatio ns/2271 [diakses 1 Agustus 2016].

Said, H., Kirgis, L., Verkamp, B., \& Johnson, L. 2015. "Online vs. Face-to-Face Delivery of Information Technology Courses: Students' Assessment". Journal of Information Technology Education: Reasearch. Vol. 14, 2015, laman web: http://www.informingscience.org/Publicatio ns/2274 [diakses 1 Agustus 2016].

Sakdiah, S, dkk. 2015. "Efektivitas Metode Pembelajaran Inkuiri Berbais Web dalam Meningkatkan Kemandirian Belajar Mahasiswa". Jurnal Pendidikan Humaniora. Vol. 3 No. 1, 2015.

Samuel, R. \& A. Zaitun. 2007. "Do Teachers have Adequate ICT Resources and the Right ICT Skills in Intergrating ICT Tools in the Teaching and Learning of English Language in Malaysia Schools?". The Electronic Journal of Information Systems in Developing Countries. 29 (2): 1-15.

Schwalbe, K. 2014. Information Technology Project Management, Seventh Edition. USA: Course Technology, Cengage Learning.
Seok, Soonhwa. (2008). "The Aspect of $E$ Learning". International Journal on Elearning, Proquest, 7(4), 725-741.

Singh, T. K. R. \& Samili, Chan. 2014. Teacher Readiness On ICT Integration In TeachingLearning: A Malaysian Case Study. International Journal of Asian Social Science. 4(7): 874-885.

Siahaan, S. 2002. Pola Penyelenggaraan Pendidikan dan Pelatihan Jarak Jauh bagi Peningkatan Kompetensi Guru. Jakarta: Seamolec.

Simonson, M. 2008. Technology use of Hispanic Bilingual Teachers: A Function of their Beliefs, Attitudes and Perceptions on Peer Technology Use in the Classroom. Journal of Instructional Technology. 31 (3): 257266.

Sudjana, N. 2005. Metode Statistika. Bandung: Tarsito.

Sugiyono. 2009. Metode Penelitian Pendidikan (Pendekatan Kuantitatif, Kualitatif, dan $R \& D)$. Bandung: Alfabeta.

Sujianto, Mukhadis, dan Isnandar. 2012. Pengembagan Prefesionalitas berkelanjutan Guru Bersertifikast Pendidik di SMK Rumpun Teknologi. Jurnal Teknologi dan Kejuruan. 35 (1): 1-16.

Sun, A., \& Chen, X. 2016. "Online Education and Its Effective Practice: A Research Review". Journal of Information Technology Education: Reasearch. Vol. 15, 2016, laman web: http://www.informingscience.org/Publicatio ns/3502 [diakses 1 Agustus 2016].

Tamba, M. 2011. Pemanfaatan Teknologi Informasi dan Komunikasi pada Pembelajaran di Sekolah Menengah Kejuruan (SMK) di Medan. Medan: Universitas Negeri Medan.

Word Bank. 2016. International Telecommunication Union, World Telecommunication/ICT Development Report and database, and World Bank Estimates, lamanweb: http://data.worldbank.org/indicator/IT.NET. USER.P2?locations=ID [diakses 1 Agustus 2016]. 